\title{
PKM PEMBUATAN KEMASAN, PENINGKATAN PRODUKSI DAN PERLUASAN PEMASARAN KERIPIK SINGKONG DI SUBANG JAWA BARAT
}

\author{
PKM MAKING PACKAGING, INCREASING PRODUCTION AND \\ EXPANSION OF MARKETING OF KERIPIK SINGKONG IN SUBANG \\ JAWA BARAT
}

Opan Arifudin

Ekonomi Syariah, STEI Al-Amar Subang

Email: opan.arifudin@yahoo.com

\begin{abstract}
Abstrak: Dalam sebuah usaha Inovasi, peningkatan produksi dan pemasaran merupakan hal yang sangat penting dalam kemajuan sebuah perusahaan. Usaha Mikro Kecil dan Menengah (UMKM) adalah sektor ekonomi nasional yang paling strategis dan menyangkut hajat hidup orang banyak sehingga menjadi tulang punggung perekonomian Nasional. Namun masalah yang dihadapi oleh usaha ataupun industri kecil saat ini adalah pengelolaan industri dan pemasaran. Dengan pengabdian masyarakat terkait pendampingan UMKM pada jenis makanan tradisional keripik singkong diharapkan dapat memberikan solusi dalam peningkatan kesejahteraan UMKM. Metode penyelesaian masalah yang digunakan berdasar pada pendekatan manajemen dalam meningkatkan hasil produksi dan hasil penjualan dengan 4 (empat) tahapan pelaksanaan program yaitu persiapan, pelaksanaan, monitoring dan evaluasi serta pelaporan. Program pengabdian masyarakat yang dilakukan adalah dengan inovasi kemasan sesuai dengan aturan Dinas Kesehatan Kota Subang, peningkatan produksi dengan pendekatan manajemen dan perluasan pemasaran pada sosial media serta pasar modern.
\end{abstract}

Kata Kunci: Inovasi, Produksi, Pemasaran

\begin{abstract}
In an innovation business, increasing production and marketing is very important in the progress of a company. Micro, Small and Medium Enterprises (MSMEs) are the most strategic national economic sector and involve the lives of many people so that it becomes the backbone of the National economy. But the problem faced by businesses or small industries today is industrial management and marketing. With community service related to assisting MSMEs on traditional types of cassava chips, it is hoped that they can provide solutions to improve MSME welfare. The problem solving method used is based on a management approach in increasing production and sales results with 4 (four) stages of program implementation, namely preparation, implementation, monitoring and evaluation and reporting. The community service program carried out is packaging innovation in accordance with the rules of the Subang City Health
\end{abstract}




\section{INTEGRITAS : Jurnal Pengabdian}

Vol 4, No 1, Juli 2020

ISSN $2580-7978$ (cetak) ISSN 2615 - 0794 (online)

Office, increasing production with a management approach and marketing expansion in social media and modern markets.

Keywords: Innovation, Production, Marketing

\section{PENDAHULUAN}

Desa Gandasoli merupakan salah satu Desa yang terletak di Kecamatan Tanjungsing Kabupaten Subang provinsi Jawa Barat. Desa Gandasoli termasuk wilayan Kabupaten Subang bagian selatan terdiri atas dataran tinggi/pegunungan yang sangat luas tanah pertaniannya. Secara spesifik bahwa sebagian besar wilayah pada bagian selatan Kabupaten Subang berupa perkebunan, baik perkebunan negara maupun perkebunan rakyat, hutan dan lokasi pariwisata. Wilayah Kabupaten Subang bagian selatan meliputi Kecamatan Serangpanjang, Sagalaherang, Jalancagak, Ciater, Cisalak, Kasomalang dan Tanjungsiang banyak terdapat area perkebunan, seperti kebun karet dan kebun teh. Selain itu juga banyak terdapat area pertanian tanaman pangan seperti padi, jagung, kacang tanah, ubi jalar dan ubi kayu yang sangat luas. Sehingga mata pencaharian utama masyarakat Subang wilayah selatan adalah bertani.

Sebagai salah satu area komoditas pertanian tanaman pangan, Kecamatan Tanjungsiang berdasar data BPS (2018) merupakan daerah yang paling banyak memproduksi ubi kayu sebagai hasil pertaniannya yaitu pada tahun 2017 dengan luas panen 507 hektar memproduksi ubi kayu sebanyak 9.527,44 ton. Penyumbang terbesar adalah dari Desa Gandasoli.

Selain bertani, mata pencaharian lain yang menjadi usaha turun temurun di Desa Gandasoli adalah pembuat keripik. Namun saat ini usaha keripik singkong rumah di Desa Gandasoli sangat sedikit. Hal ini disebabkan karena usaha keripik singkong ini, dianggap kurang menguntungkan karena besarnya biaya produksi dan minimnya tempat pemasaran keripik singkong.

Sehingga pelaksanaan kegiatan pengabdian masyarakat ini berupaya membantu pengembangan usaha keripik singkong. Pengabdian masyarakat merupakan tridharma yang harus dilakukan oleh seorang dosen. Oleh karena itu, 


\section{INTEGRITAS : Jurnal Pengabdian}

Vol 4, No 1, Juli 2020

ISSN $2580-7978$ (cetak) ISSN 2615 - 0794 (online)

pengabdian masyarakat ini dilakukan dalam upaya mendampingi usaha keripik singkong di Desa Gandasoli Kecamatan Tanjungsiang Kabupaten Subang Provinsi Jawa Barat.

\section{Permasalahan Mitra}

Kondisi eksisting mitra saat ini, adalah sebagai berikut :

a. Usaha mitra belum memiliki P-IRT

b. Mitra mengalami kendala dalam melakukan proses pengurusan P-IRT karena kondisi tempat produksi usaha yang tidak memenuhi syarat.

c. Mitra tidak memiliki kemasan yang memadai untuk dijual lebih luas.

d. Minimnya pengetahuan akan pemanfaatan manajemen dalam proses produksi

e. Rendahnya pengetahuan untuk memasarkan produk, akibat ketidakmampuan memahami dunia teknologi dapat menghambat kemajuan usaha

f. Tempat pemasaran yang sangat minim

\section{Solusi PKM}

1. Membantu pengurusan ijin usaha dan P-IRT sehingga keripik singkong dapat dijual lebih luas lagi.

2. Memperbaiki kemasan produk keripik singkong dengan membuat kemasan didesain sesuai dengan standar yang telah di tetapkan Dinas Kesehatan dan agar lebih menarik.

3. Menerapkan manajemen pada proses produksi UMKM keripik singkong.

\section{Luaran PKM}

1. Menumbuhkan inovasi dalam menjalankan usaha.

2. Meningkatkan etos kerja dengan pendekatan manajemen.

3. Meningkatkan pengetahuan mengenai pemasaran konvensional maupun online.

4. Meningkatkan pendapatan UMKM keripik singkong. 


\section{INTEGRITAS : Jurnal Pengabdian}

Vol 4, No 1, Juli 2020

ISSN 2580 - 7978 (cetak) ISSN 2615 - 0794 (online)

\section{METODE PELAKSANAAN}

Metode dalam pelaksanaan program pengabdian masyarakat dalam mendampingi UMKM Keripik Singkong Desa Gandasoli Kecamatan Tanjungsiang Kabupaten Subang Jawa Barat dilakukan dengan beberapa tahapan pelaksanaan program, yaitu sebagai berikut :

1. Tahapan awal

a. Tahapan ini dilakukan dengan menyiapkan data-data yang dibutuhkan terkait UMKM Keripik Singkong Desa Gandasoli Kecamatan Tanjungsiang Kabupaten Subang Jawa Barat. Hal ini dibutuhkan untuk memastikan pendampingan seperti apa yang tepat dengan juga melihat kultur di Desa yang bersangkutan sebagai pertimbangan dalam proses pendampingan.

b. Menyiapkan program-program pengabdian masyarakat untuk di sosialisasikan kepada UMKM Keripik Singkong Desa Gandasoli Kecamatan Tanjungsiang Kabupaten Subang Jawa Barat dengan design utama adalah pembuatan kemasan baru dan peningkatan produksi keripik singkong.

c. Menyiapkan peralatan, sarana-prasarana pendukung untuk pelaksanaan program dan formula strategi pelaksanaan program secara tahap demi tahap berdasarkan prioritas program pendampingan UMKM Keripik Singkong Desa Gandasoli Kecamatan Tanjungsiang Kabupaten Subang Jawa Barat.

2. Tahapan pelaksanaan

a. Mengemukakan strategi proses pelaksanaan program pendampingan UMKM Keripik Singkong untuk menerapkan pola manajemen terhadap mitra sehingga diharapkan memberikan dampak dan perubahan terhadap mitra sasaran program sesuai dengan tujuan pengabdian masyarakat pendampingan UMKM Keripik Singkong Desa Gandasoli Kecamatan Tanjungsiang Kabupaten Subang Jawa Barat.

b. Tahapan pelaksanaan ini merupakan adanya komunikasi sinergi dengan mitra terkait keaktifan, peran dan kontribusi mitra sasaran pelaksanaan 


\section{INTEGRITAS : Jurnal Pengabdian}

Vol 4, No 1, Juli 2020

ISSN 2580 - 7978 (cetak) ISSN 2615 - 0794 (online)

program pengabdian masyarakat pendampingan UMKM Keripik Singkong

Desa Gandasoli Kecamatan Tanjungsiang Kabupaten Subang Jawa Barat.

c. Dalam proses pengabdian masyarakat pendampingan UMKM Keripik Singkong akan dilakukan terus koordinasi terkait progres dari pengabdian masyarakat pendampingan UMKM Keripik Singkong Desa Gandasoli Kecamatan Tanjungsiang Kabupaten Subang Jawa Barat ini baik berupa data kuantitatif yang diukur selama pelaksanaan program.

d. Data kuantitatif ini merupakan referensi yang terus dipantau oleh Dosen pengabdi yang dihasilkan pada mitra sasaran sebagai data hasil kegiatan, baik data secara kuantitatif (misalnya jumlah produksi, jumlah omzet, jumlah kader masyarakat, luasan lahan, jumlah tanaman dll) maupun data kualitatif (misalnya kualitas produk, jenis produk, diversifikasi produk, perubahan perilaku masyarakat, keberadaan manajemen usaha/manajemen sosial dan sebagainya).

3. Tahapan monitoring dan evaluasi

a. Proses monitoring dan evaluasi terhadap pelaksanaan program dilakukan setiap minggu dalam 3 (tiga) bulan masa pengabdian masyarakat pendampingan UMKM Keripik Singkong Desa Gandasoli Kecamatan Tanjungsiang Kabupaten Subang Jawa Barat.

b. Metode evaluasinya yang digunakan menggunakan metode deskriptif yaitu penelitian lapangan (Field Research) dengan penyelidikan mendalam yang dilakukan dengan suatu prosedur penelitian lapangan. Penelitian ini juga menggunakan data deskriptif kualitatif, yaitu penelitian yang ditujukan untuk mendiskripsikan atau menggambarkan fenomena-fenomena yang ada, baik fenomena yang bersifat alamiah ataupun rekayasa manusia

4. Tahap pelaporan

Pada tahapan ini, dilaporkan semua proses rangkaian kegiatan pengabdian dan output dari kegiatan ini. 


\section{INTEGRITAS : Jurnal Pengabdian}

Vol 4, No 1, Juli 2020

ISSN $2580-7978$ (cetak) ISSN 2615 - 0794 (online)

\section{HASIL DAN PEMBAHASAN}

Berdasarkan hasil dari pengabdian masyarakat dengan program pendampingan UMKM Keripik Singkong Desa Gandasoli Kecamatan Tanjungsiang Kabupaten Subang Jawa Barat dapat dijelaskan hasil dan luaran program serta dampaknya terhadap perubahan mitra selama proses pendampingan menghasilkan inovasi kemasan Keripik Singkong dan mengalami peningkatan secara signifikan secara produksi.

Dampak dari program pengabdian masyarakat dengan program pendampingan UMKM Keripik Singkong Desa Gandasoli Kecamatan Tanjungsiang Kabupaten Subang Jawa Barat terhadap mitra sangat besar terkait peningkatan penjualan dari produksi berdasar data setiap bulan dengan rentang waktu pendampingan selama 3 (tiga) bulan dari bulan agustus, September dan oktober tahun 2019. Perlu diketahui bahwa dalam penyelenggaraan produksi ini melibatkan 5 (lima) orang pekerja pada UMKM Keripik Singkong Desa Gandasoli Kecamatan Tanjungsiang Kabupaten Subang Jawa Barat. Program yang dilakukan adalah pendekatan manajemen pemasaran pola pemasaran dan produksi Keripik Singkong. Hal ini merupakan perubahan dari kemasan Keripik Singkong dan peningkatan produksi yang dihasilkan untuk dipasarkan.

Hal ini dapat dilihat dari berbagai tahapan pengabdian masyarakat yang dilakukan yakni sebagai berikut :

\section{Tahap Persiapan}

Pada tahap ini dilaksanakan observasi ke lokasi mitra dan wawancara dengan pemilik usaha. Dari hasil observasi dan wawancara dengan mitra ditemukan permasalahan yang dialami oleh mitra sebagai berikut:

a. Usaha mitra belum memiliki P-IRT

b. Mitra mengalami kendala dalam melakukan proses pengurusan P-IRT karena kondisi tempat produksi usaha yang tidak memenuhi syarat.

c. Mitra tidak memiliki kemasan yang memadai untuk dijual lebih luas.

Permasalahan-permasalahan di atas perlu diatasi agar usaha mitra dapat lebih berkembang lagi. Menurut Titik dan Purwaning Budi (2017). 


\section{INTEGRITAS : Jurnal Pengabdian}

Vol 4, No 1, Juli 2020

ISSN $2580-7978$ (cetak) ISSN 2615 - 0794 (online)

Mengembangkan usaha kecil menengah dalam masyarakat merupakan salah satu upaya penting yang dapat dilakukan untuk meningkatkan kesejahteraan masyarakat. Berdasarkan permasalahan yang ditemui di atas maka solusi yang ditawarkan pengabdian kepada masyarakat pada UMKM Keripik Singkong sebagai mitra dalam kegiatan pengabdian ini terbagi pada aspek produksi dan pemasaran produk, yaitu:

1) Aspek Produksi

Solusi dari aspek produksi yang ditawarkan oleh dosen pendamping dalam pengabdian ini adalah sebagai berikut :

a. Membantu pengurusan ijin usaha dan P-IRT sehingga keripik singkong dapat dijual lebih luas lagi.

b. Memperbaiki kemasan produk Keripik singkong dengan membuat kemasan didesain sesuai dengan standar yang telah di tetapkan Dinas Kesehatan dan agar lebih menarik.

c. Menerapkan manajemen pada proses produksi UMKM keripik singkong.

2) Aspek Pemasaran

Keripik Singkong berkualitas yang telah dihasilkan dapat memperluas tempat pemasaran. Menurut Mahmudah dan Supri Wahyudi (2017) Pasar yang dipilih untuk pemasaran juga harus tepat karena pasar merupakan tempat bertemunya penjual dan pembeli hingga terjadi suatu transaksi. Hal ini sejalan dengan pendapat Kasmir (2013) bahwa transaksi yang terjadi dalam pasar tersebut merupakan kegiatan jual beli produk. Solusi dari permasalahan pemasaran yang ditawarkan dalam Program Kemitraan Masyarakat ini adalah memperluas pemasaran ke pasar modern dan pemasaran secara online.

\section{Tahap Pelaksanaan}

Solusi yang ditawarkan pada tahap persiapan baik aspek produksi maupun aspek pemasaran dilaksanakan pada tahap pelaksanaan ini, kegiatan yang dilaksanakan pada tahap ini adalah sebagai berikut : 


\section{INTEGRITAS : Jurnal Pengabdian}

Vol 4, No 1, Juli 2020

ISSN $2580-7978$ (cetak) ISSN 2615 - 0794 (online)

a. Aspek Produksi

1) Meningkatkan kualitas produksi

Dalam produksi mitra mengalami masalah karena proses produksi dilakukan tanpa pendekatan manajemen. Hal ini terlihat dari jam kerja yang tidak jelas, perencanaan produksi yang belum ada dan capaian produksi yang tidak jelas setiap waktunya.

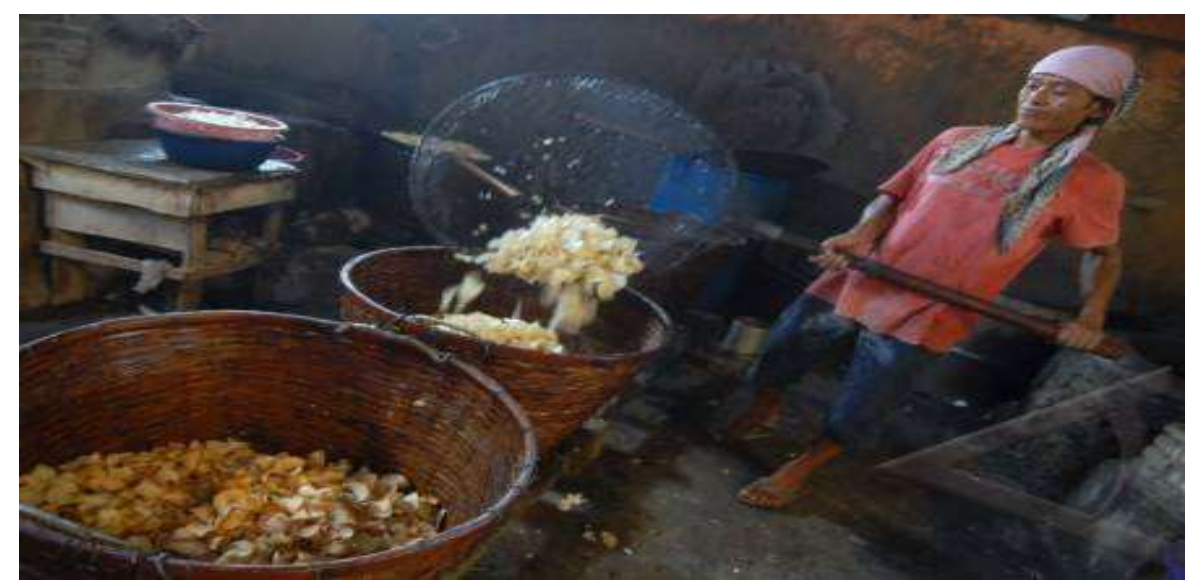

Gambar 1. Proses Produksi Keripik Singkong

2) Mengurus Sertifikat Industri Rumah Tangga Pangan (P-IRT) dan izin usaha.

Sertifikat Industri Rumah Tangga Pangan (P-IRT) dikeluarkan oleh Dinas Kesehatan Kota Subang setelah melalui beberapa proses. Tim pengabdian masyarakat mendampingi mitra untuk mengurus izin usaha dan PIRT. Sebagian besar masyarakat pemilik UMKM termasuk mitra merasakan kesulitan dalam mengurus PIRT karena mereka tidak mengerti dengan proses yang harus dilewati padahal sesungguhnya prosesnya sangat mudah dan jelas di Dinas Kesehatan. Tim pengabdian masyarakat mendampingi mitra dalam setiap proses mendapatkan sertifikat P-IRT. Ada beberapa berkas yang harus dipersiapkan oleh mitra sebagai pengajuan awal yaitu Mengisi formulir yang telah disediakan, Fotokopi Sertifikat Penyuluhan Keamanan Pangan (PKP), Fotokopi Kartu Tanda Penduduk pemilik perusahaan, Fotokopi hasil pemeriksaan air atau bukti pembayaran rekening PDAM, Denah lokasi industry, Denah ruang produksi, Rancangan label pangan, Daftar produk yang 


\section{INTEGRITAS : Jurnal Pengabdian}

Vol 4, No 1, Juli 2020

ISSN $2580-7978$ (cetak) ISSN 2615 - 0794 (online)

diajuakan dan Nomor induk berusaha (Izin Usaha). Berkas-berkas yang dibutuhkan dipersiapkan dan di serahkan ke Dinas kesehatan Kota Subang.

Dinas Kesehatan Kota Subang melakukan visitasi ke lokasi produksi keripik singkong untuk melihat kelayakan tempat produksi dan kelayakan produknya sendiri untuk mendapatkan sertifikat PIRT. Bahan dasar yang digunakan serta proses pengolahan produk juga menjadi sorotan utama dari tim visitasi Dinas Kesehatan. Dari hasil kunjungan tim visitasi Dinas Kesehatan Kota Subang terdapat beberapa masukan yang harus dipenuhi oleh mitra agar proses pengurusan PIRT dapat dilanjutkan. Masukan dari Dinas Kesehatan tersebut adalah menyediakan sabun cuci tangan dan cuci piring yang berbeda dan juga ada lap kering, membuat catatan penjualan dan segera membuang sampah limbah produksi. Mitra diberikan waktu 10 hari untuk memperbaiki lokasi produksi dan hal-hal lainnya sesuai dengan saran dari tim visitasi Dinas kesehatan Kota Subang.

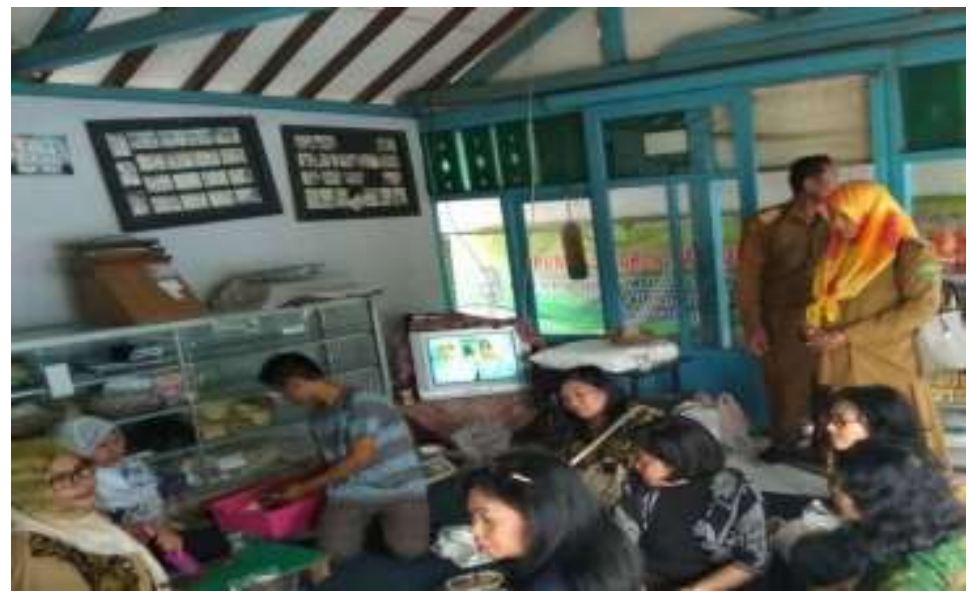

Gambar 2. Kunjungan Dinas Kesehatan Kota Subang untuk Pengurusan PIRT

Tim pengabdian masyarakat mendampingi mitra untuk melengkapi ataupun memperbaiki sarana dan prasarana proses produksi sesuai dengan saran dari tim visitasi Dinas Kesehatan Kota Subang. Semua perbaikan yang dilakukan sesuai dengan saran dari tim visitasi Dinas Kesehatan Kota Subang dilaporkan dan berkas-berkas yang harus dilengkapi diserahkan kembali ke bagian pengurusan PIRT di Dinas Keseshatan Kota Subang. Setelah melewati 


\section{INTEGRITAS : Jurnal Pengabdian}

Vol 4, No 1, Juli 2020

ISSN $2580-7978$ (cetak) ISSN 2615 - 0794 (online)

semua proses untuk mendapatkan sertifikat P-IRT, akhirnya keripik singkong berhasil memiliki sertifikat Industri Rumah Tangga Pangan (P-IRT) yang berlaku selama 4 tahun dan siap untuk dikunjungi lagi sewaktu-waktu.

\section{3) Desain Kemasan}

Pada tahapan ini dihasilkan desain kemasan yang lebih baik dari sebelumnya. Kemasan didesain sesuai syarat yang telah ditetapkan oleh Dinas Kesehatan Kota Subang yaitu minimal memuat nama pangan, merk, netto/berat bersih, komposisi, tanggal kadarluarsa, kode produksi, nama dan alamat IRTP (minimal kabupaten, Indonesia, kode pos), nomor PIRT, serta tidak mencantumkan klaim kesehatan atau klaim gizi. Kemasan produk didesain sesuai produk keripik singkong yang dibuat.

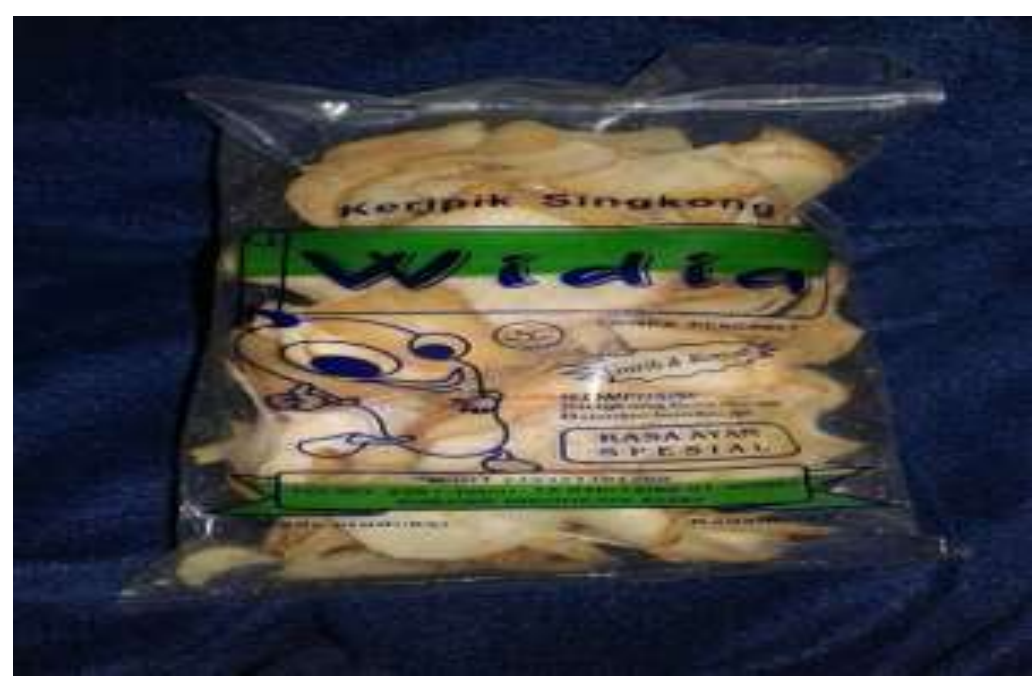

Gambar 3. Desain kemasan produk keripik singkong

b. Aspek Pemasaran

Pemasaran merupakan serangkaian kegiatan yang dilakukan oleh produsen sebagai upaya menjual produk yang dihasilkan kepada konsumen. Mitra didampingi tim pengabdi mengembangkan pemasaran melalui dua cara pemasaran 


\section{INTEGRITAS : Jurnal Pengabdian}

Vol 4, No 1, Juli 2020

ISSN $2580-7978$ (cetak) ISSN 2615 - 0794 (online)

1) Pengembangan pemasaran ke pasar modern

Saat ini banyak konsumen yang memilih berbelanja di pasar modern. Pada pasar modern, penjual dan pembeli tidak bertemu secara langsung. Pengembangan pemasaran ditargetkan dapat menembus ke toko-toko yang lebih besar (toko modern). Mitra didampingi tim pengabdi melakukan survey ke beberapa toko, minimarket dan supermarket untuk dapat memperluas pemasaran. Toko-toko modern tersebut memiliki beberapa standar produk yang dapat dijual ditokonya. Minimal produk telah memiliki sertifikat PIRT yang dikeluarkan oleh Dinas Kesehatan setempat.

Setelah sertifikat nomor PIRT didapat, tim pengabdi mendampingi mitra dalam upaya memasarkan produknya ke toko-toko modern. Mitra perlu didampingi dalam memperkenalkan produknya ke toko-toko modern karena keterbatasan pengetahuan dan kurangnya pengalaman mitra membuat mitra merasa kurang percaya diri untuk memasarkan produknya ke toko-toko besar yakni supermarket. Beberapa minimarket telah menerima produk keripik singkong untuk dipasarkan disana. Sebagian masih proses penyeleksian oleh toko.

2) Pengembangan pemasaran secara online

Menurut Himawan, Asep, dan Sugeng (2014) bahwa untuk memperluas pemasaran dan menjangkau konsumen lebih banyak lagi dapat dilakukan dengan pemasaran secara online. Website dan media sosial lainnya seperti facebook dan instagram dapat digunakan sebagai tempat promosi dan transaksi jual beli. Tim pengabdian masyarakat mendampingi mitra dalam menggunakan sosial media untuk memasarkan produknya. Mitra memerlukan pelatihan dan pendampingan secara terus menerus. Keterbatasan ibu-ibu mitra dalam menggunakan teknologi menyulitkan mitra dalam menjual produk secara online. Mitra terus berlatih untuk menggunakan sosial media untuk berjualan online. 


\section{INTEGRITAS : Jurnal Pengabdian}

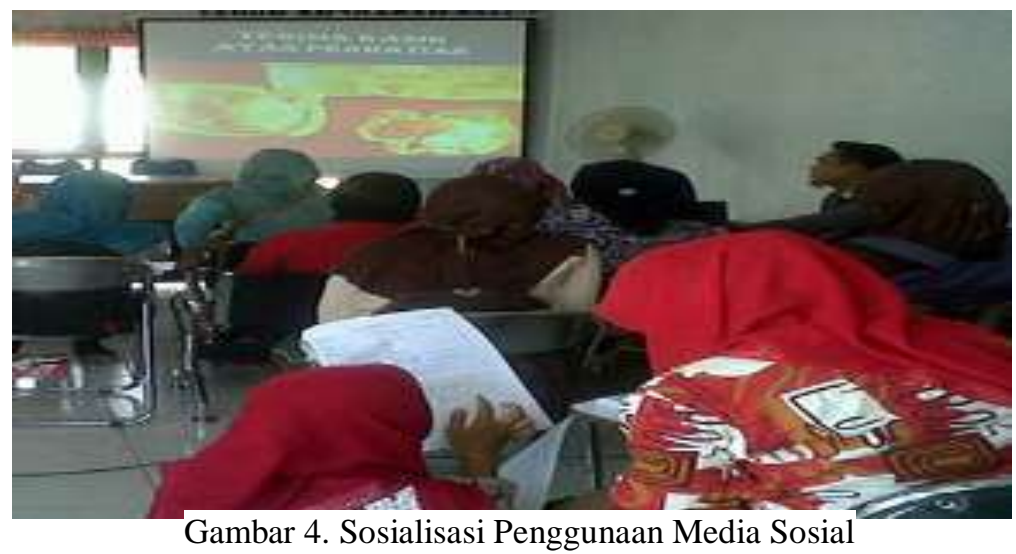

\section{Tahap Evaluasi}

a. Evaluasi Perkembangan Usaha Mitra

Pada tahap evaluasi ini diukur keberhasilan program pengabdian masyarakat yang telah dilaksanakan terhadap usaha mitra. Evaluasi dilakukan terhadap dua aspek, yaitu :

1) Aspek Produksi

Kelayakan proses produksi juga telah mendapatkan jaminan dari Dinas Kesehatan Kota Subang. Pada tanggal 18 September 2018 telah diterbitkan Surat Keputusan Kepala Dinas Kesehatan Kota Subang tentang Pemenuhan Komitmen Sertifikat Nomor Pangan Industri Rumah Tangga "Keripik Singkong Widya". Dinas Kesehatan Kota Subang telah menyatakan bahwa Keripik Singkong Widya layak dan mendapatkan nomor P-IRT yang berlaku hingga 28 September 2022.

2) Aspek Pemasaran

Dari segi pemasaran telah mengalami peningkatan penjualan. Tabel berikut ini memberikan rekapan penjualan keripik singkong pada bulan Agustus, September dan Oktober dari tahun 2016, 2017, dan 2018. Untuk data penjualan secara rinci dapat dilihat pada grafik di bawah ini. 


\section{INTEGRITAS : Jurnal Pengabdian}

Vol 4, No 1, Juli 2020

ISSN $2580-7978$ (cetak) ISSN $2615-0794$ (online)

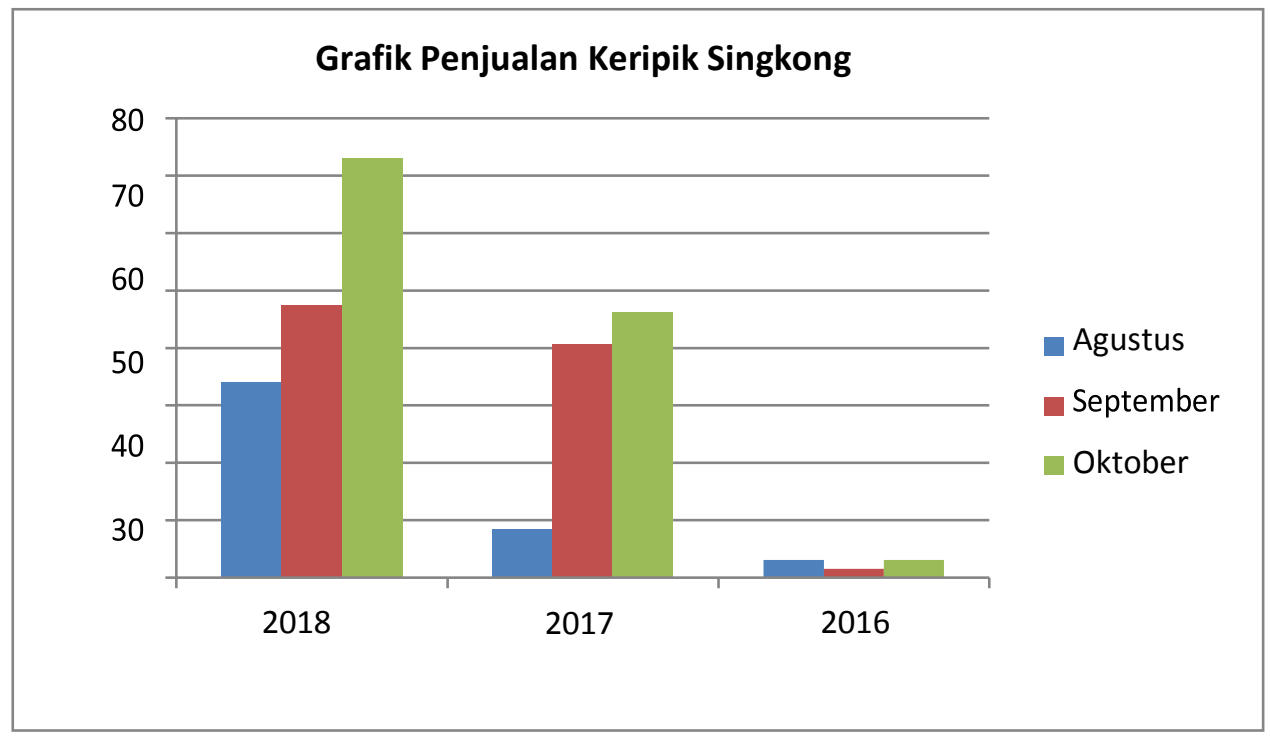

Gambar 5. Peningkatan penjualan Keripik Singkong dari tahun 2016-2018

\section{b. Evaluasi Proses Kegiatan Pengabdian}

Setiap tahapan kegiatan pengabdian telah dilaksanakan sesuai dengan rencana awal kegiatan. Output dari kegiatan juga telah sesuai dengan rencana. Berdasarkan wawancara yang dilakukan dengan mitra, kegiatan pengabdian ini juga telah memberikan manfaat yang besar bagi mitra. Hal ini terbukti dengan pemasaran yang semakin luas dan peningkatan omset penjualan setiap harinya.

Ada beberapa hal yang menjadi kendala dalam pelaksanaan kegiatan pengabdian ini, yaitu :

1) Susahnya mencari waktu yang pas untuk melatih mitra pemasaran online, karena mitra rata-rata adalah ibu rumah tangga.

2) Kondisi mitra yang merupakan ibu-ibu rumah tangga yang tidak akrab dengan teknologi membutuhkan waktu yang cukup lama untuk melatih kemampuan mitra menggunakan website dan media sosial.

3) Kurangnya kepercayaan diri mitra untuk memperluas produknya ke pasarpasar modern. 


\section{INTEGRITAS : Jurnal Pengabdian}

Vol 4, No 1, Juli 2020

ISSN $2580-7978$ (cetak) ISSN 2615 - 0794 (online)

4) Proses pembuatan sertfikat P-IRT memerlukan waktu yang cukup lama karena antrian pemohon di Dinas Kesehatan Subang yang cukup banyak sehingga membuat proses pemasaran juga terlambat.

\section{Tahap Pelaporan}

Pada tahapan ini, dilaporkan semua proses rangkaian kegiatan pengabdian dan output dari kegiatan ini. Luaran yang telah diperoleh juga dilaporkan pada tahapan ini. Luaran yang telah diperoleh adalah artikel, poster kegiatan, modul, dan brosur promosi.

\section{KESIMPULAN DAN SARAN}

\section{Kesimpulan}

Kesimpulan dari program pengabdian masyarakat Dosen STEI Al-Amar Subang dengan program pendampingan UMKM Keripik Singkong Kabupaten Subang Jawa Barat terhadap mitra dalam inovasi kemasan, meningkatkan jumlah produksi dan hasil penjualan, hal ini sesuai dengan design awal program pendampingan terhadap mitra berdasarkan data-data yang ada diperoleh 3 (tiga) bulan sebelum pendampingan.

Program pendampingan UMKM Keripik Singkong Kabupaten Subang Jawa Barat, terkait perubahan yang dialami oleh mitra program selama dan setelah pelaksanaan program dilakukan dapat dilihat dari 2 indikator perubahan yang dapat disimpulkan berdasar pada data-data yang diperoleh dalam setiap monitoring dan evaluasi program terhadap mitra. Indikator ini terdiri dari inovasi kemasan dan perluasan pasar keripik singkong.

\section{Saran}

Adapun saran yang bisa diberikan atas pelaksanaan Program pengabdian kepada masyarakat kepada UMKM Keripik Singkong Kabupaten Subang Jawa Barat, adalah sebagai berikut :

1. Untuk terus konsisten dalam menjalankan UMKM keripik singkong dibutuhkan pendekatan manajemen yang konsekuen sehingga perbaikan bukan 


\section{INTEGRITAS : Jurnal Pengabdian}

Vol 4, No 1, Juli 2020

ISSN $2580-7978$ (cetak) ISSN 2615 - 0794 (online)

saat pendampingan saja tetapi juga menjadi budaya baru UMKM keripik singkong.

2. Dibutuhkan semangat terus belajar guna terus berinovasi dalam pengembanag usaha ke depan agar bisa bersaing dengan usaha yang lain.

3. Adanya kesamaan tujuan antara pemilik dan karyawan agar UMKM keripik singkong ini bisa mensejahteraan kehidupan semuanya.

\section{UCAPAN TERIMA KASIH}

Syukur Alhamdulillah penulis panjatkan kehadirat Allah SWT, atas berkat rahmat Alloh yang Maha pengasih penulis dapat menyelesaikan karya tulis jurnal pengabdian masyarakat ini dengan sebaik-baiknya. Penulis menyadari sepenuhnya bahwa kerjasama dan bantuan berbagai pihak sangat membantu dalam menyelesaikan jurnal pengabdian masyarakat ini. Oleh sebab itu, di dalam kesempatan ini penulis ingin menyampaikan ucapan terima kasih dan penghargaan yang setinggi-tingginya khususnya kepada :

1. Bapak Juhadi, S.Kom, M.Si selaku ketua STEI Al-Amar Subang sebagai penyandang dana pengabdian masyarakat

2. Ketua LP3M STEI Al-Amar Subang

3. Bapak Usman Amarullah, selaku pemilik UMKM

4. Semua pihak yang tidak bisa penulis sebutkan satu persatu, yang telah memberikan bantuan dalam penyelesaian jurnal pengabdian masyarakat ini.

\section{DAFTAR PUSTAKA}

Freeman. (2004). Stakeholder Theory and the Corporate Objective Revisited". Organization Science. Vo. 15 No.3

Himawan, Asep, S., \& Sugeng, S. (2014). Analisa dan Perancangan Sistem Informasi Penjualan Online (E-Commerce) Pada CV Selaras Batik Menggunakan Analisa Deskriptif. Scientific Journal Of Informatics, 1(1), 53-63.

Mahmudah, M., \& Supri Wahyudi, U. (2017). Analisis Dampak Keberadaan Pasar Modern Terhadap Pasar Tradisional Sleko di Kota Madiun. Assets: Jurnal Akuntansi Dan Pendidikan, 6(1), 59-72. https://doi.org/10.25273/jap.v6i1.1293. 
INTEGRITAS : Jurnal Pengabdian

Vol 4, No 1, Juli 2020

ISSN $2580-7978$ (cetak) ISSN 2615 - 0794 (online)

Miller, R.L. dan Meiners E, R. (2000). Teori Mikroekonomi Intermediate, penerjemah Haris Munandar. PT. Raja Grafindo Persada, Jakarta.

Kasmir. (2013). kewiraushaan (Revisi). Jakarta: PT. Raja Grafindo Persada.

Kotler, Philip, dan Gary Armstrong 2012. Prinsip-prinsip Pemasaran. Edisi 13. Jilid 1. Erlangga: Jakarta.

Pervaiz K. Ahmed dan Charles D. Shepherd (2010). Innovation Management. New Jersey : Pearson Education. Inc

Sadono Sukirno. (2008). Mikroekonomi: Teori Pengantar. Edisi Ketiga. Jakarta: PT Raja Grafindo Persada.

Tambajong, 2013, Bauran Pemasaran Pengaruhnya Terhadap Penjualan Sepeda Motor Yamaha Di PT. Sarana Niaga Megah Kerta Manado, Jurnal EMBA, Vol.1 No.3 September 2013, Hal. 1291-1301.

Titik, W., \& Purwaning Budi, L. (2017). Ibm-Pendampingan Usaha Kerupuk Rumahan Di Desa Kembang Kabupaten Pacitan. Jurnal ABDIMAS Unmer Malang, 2(01). 